\title{
Optimum conditions for isoamylase production by Pseudomonas sp.
}

Pseudomonas sp. تعيين الظروف المثلى لإنتاج إنزيم ايسواميليز بوساطة بكتريا

$$
\begin{aligned}
& \text { Hameed M. Jasim Haneen S. Abdul-Wahab* } \\
& \text { حميد مجيد جاسم علية العلوم / جامعة النهرين سعدون عبد الوهابز }
\end{aligned}
$$

\begin{abstract}
Different nutritional and cultural factors were studied to determine the optimum conditions for isoamylase production by Pseudomonas sp. in a batch culture of the production medium. These factors include carbon, nitrogen and phosphate sources and their concentrations, temperature and $\mathrm{pH}$. Results showed that the optimum conditions for isoamylase production by Pseudomonas $\mathrm{sp}$. were achieved when the production medium was supplemented with maltose $1 \%$, peptone $0.4 \%$, and $\mathrm{K}_{2} \mathrm{HPO}_{4} \mathbf{0 . 4 \%}$ as a carbon, nitrogen, and phosphate sources respectively, at initial medium $\mathrm{pH} 6$, and incubation at $28^{\circ} \mathrm{C}$ for 24 hours. Under these conditions isoamylase productivity reaches the maximum, at which enzyme specific activity was $0.85 \mathrm{U} / \mathrm{mg}$ proteins.

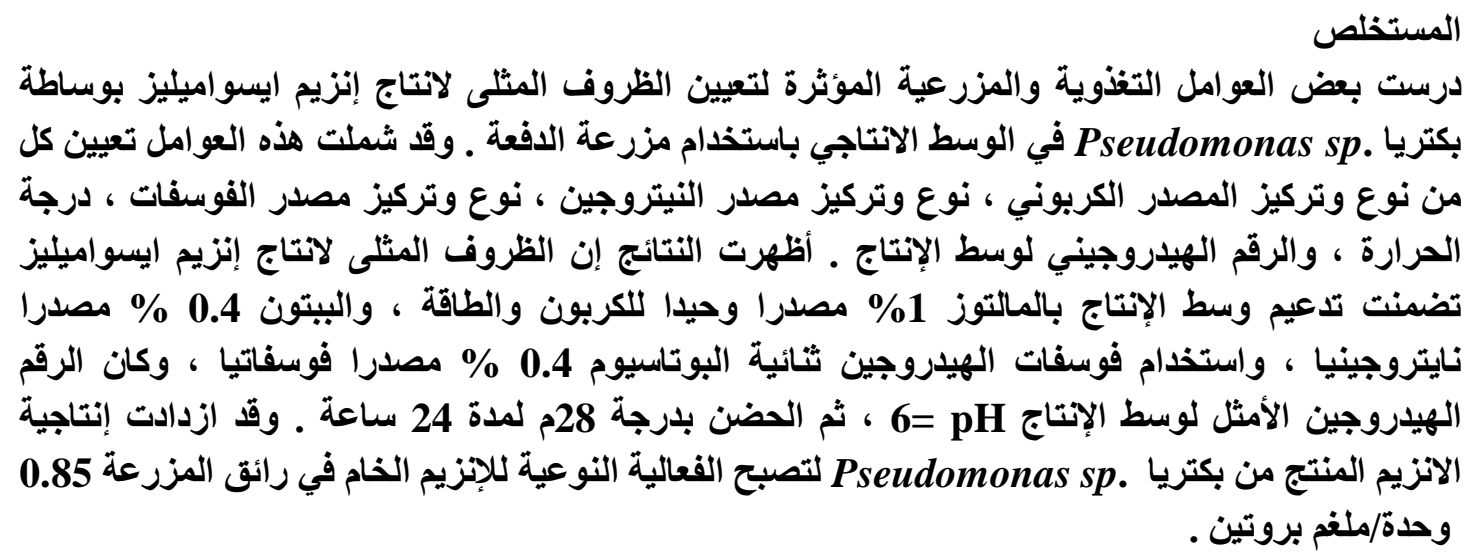

\section{Introduction}

The use of enzymes is preferred as it offers a number of advantages including improved yields and favourable economics [1,2]. Isoamylase was first discovered in autolysed brewers' yeast. This intracellular enzyme has also been found in baker's yeast [3]. An extracellular yeast isoamylase has been reported by [4] from Lypomyces kononenkoae by identified an extracellular isoamylase produced by Escherichia coli then from Pseudomonas amyloderamosa which was then purified and characterized [5,6]. Isoamylase (amylopectin-6-glucanohydrolase or glycogen-6-glucanohydrolase, EC 3.2.1.68) catalyzes the hydrolysis of $\alpha-1,6$-glucosidic linkages of amylopectin and related polysaccharides $[7,8]$. Isoamylase is useful not only for the structural analysis of polysaccharides and derived oligosaccharides [9] but also for the starch industry [10] in producing glucose, maltose and higher oligosaccharides from starch with the action of exo-type hydrolases. Isoamylase also can be used in conjunction with 
CGTase to enhance the production of cyclodextrins from starch $[11,12]$ and to improve their solubility and hemolytic product through the reversed action of enzyme. The genus Bacillus has been in use in the biotechnology industry for a very long time with a number of new cultures exhibiting a variety of benefits to humans $[13,14]$. The main objective of this study is to determine the optimum conditions for enzyme production by a local isolate of Pseudomonas sp.

\section{Materials and Methods}

\section{Microorganism and media}

Pseudomonas sp. was isolated in a previous study [15]. The isolate was maintained on nutrient agar slants and stored at $4^{\circ} \mathrm{C}$ as a stock culture, while nutrient broth medium was used for the activation and preparation of bacterial inoculum. Isoamylase production was achieved in the production medium containing (per liter): 20g, maltose; 4g, sodium glutamate; 3g, Diammonium hydrogen phosphate [16].

\section{Optimization of Isoamylase production}

The optimization experiments were carried out aerobically under batch cultivation conditions in the production medium. Fifty $\mathrm{ml}$ of this medium was distributed in 250 $\mathrm{ml}$ Erlenmeyer flasks inoculated with $1 \%$ of mid-exponential phase culture of the Pseudomonas sp., and incubated with shaking at 150rpm in a shaker incubator at $28 \mathrm{C}^{\circ}$. Optimization conditions include the type and concentration of carbon, nitrogen, and phosphate sources, effect of $\mathrm{pH}$, and temperature.

\section{Enzyme assay}

Assay of isoamylase was achieved according to [17], by adding $1 \mathrm{ml}$ of the crude enzyme to the reaction mixture containing $5 \mathrm{ml}$ of $1 \%$ soluble glutinous rice starch solution, $1 \mathrm{ml}$ of $0.5 \mathrm{M}$ acetate buffer $\mathrm{pH} 3.5$. After incubation at $40^{\circ} \mathrm{C}$ for $1 \mathrm{hr}, 1 \mathrm{ml}$ of the reaction mixture was taken and mixed with $1 \mathrm{ml}$ of $0.01 \mathrm{~N}$ of iodine solution, then the volume was completed to $25 \mathrm{ml}$ with distilled water. The increase in the optical density at $610 \mathrm{~nm}$ was measured using a photocell $(1 \mathrm{~cm}$ wide) and the enzyme activity was determined according to the following equation:

\section{Enzyme activity $(\mathrm{U} / \mathrm{ml})=$ Abs $(610 \mathrm{~nm}) / 1 \times 0.01 \times 60$}

Activity unit was defined as the amount of enzyme increase the absorbance up to 0.01 at $40^{\circ} \mathrm{C}$ under the reaction conditions [18].

\section{Protein Concentration}

Protein concentration in culture medium was determined according to [19] by using Coomassie blue G-250 and Bovine serum albumin standard solution.

\section{Results and Discussion}

\section{Effect of carbon source}

Six carbon sources (Lactose, sucrose, fructose, galactose, glucose and maltose) were used as a sole sources for carbon and energy to select the optimum for isoamylase production by Pseudomonas sp. H3. Results mentioned in Figure (1) showed that the maximum production of isoamylase was obtained when the production medium was supplemented with maltose as a soul source for carbon and energy. Enzyme specific activity in crude filtrate was $0.42 \mathrm{U} / \mathrm{mg}$ proteins. 


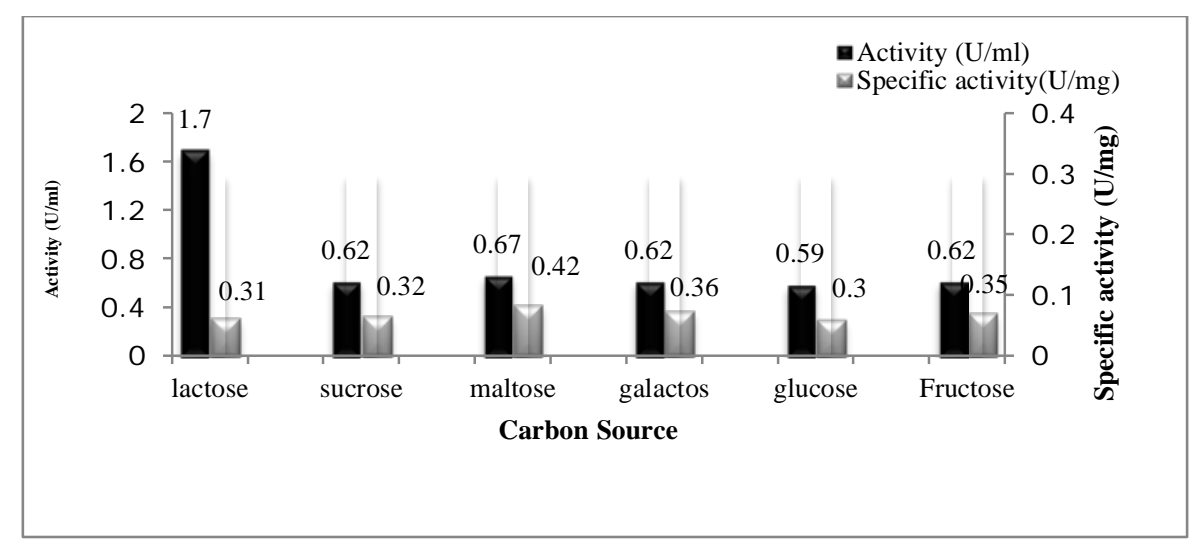

Fig (1): Effect of carbon source on isoamylase production by Pseudomonas sp. H3 after incubation in shaker incubator $(150 \mathrm{rpm})$ at $28^{\circ} \mathrm{C}$ for $24 \mathrm{hr}$.

On the other hand $[20,21]$ were found that maltose was the optimum for isoamylase production by Aerobacter aerugenes .

\section{Effect of carbon source concentration}

Different concentrations of maltose were used to determine the optimum for isoamylase production by Pseudomonas sp. H3. Results indicated in Figure (2) showed that the maximum production of isoamylase was obtained when maltose was used in a concentration of $2 \%$.The specific activity of isoamylase was $0.53 \mathrm{U} / \mathrm{mg}$ in culture filtrate. This indicates that this concentration of carbon source is the best for providing the microorganism with the needed energy for growth. This result was agreed with [22], who found that the maximum isoamylase production was obtained when maltose was used as a sole source for carbon and energy at concentration of $1.1 \%$.

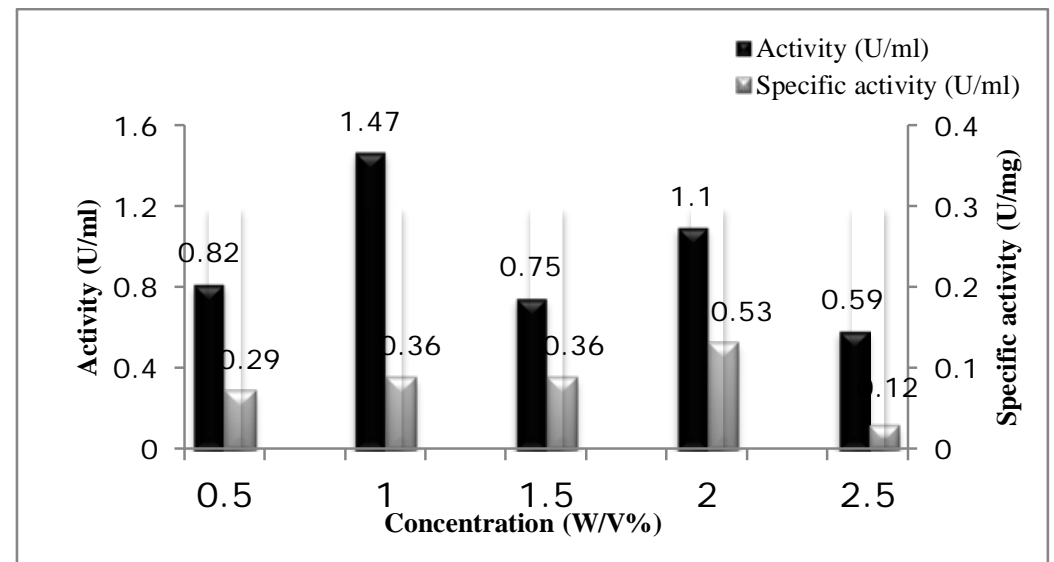

Fig (2): Effect of maltose concentration on isoamylase production by Pseudomonas sp. H3 after incubation in shaker incubator $(150 \mathrm{rpm})$ at $28^{\circ} \mathrm{C}$ for $24 \mathrm{hrs}$.

\section{Effect of nitrogen source}

Different nitrogen sources (peptone, tryptone, yeast extract, $\mathrm{NH} 4 \mathrm{Cl}$ and $\mathrm{NH} 4 \mathrm{NO} 3$ ), were added to the production medium to determine the optimum for isoamylase production by Pseudomonas sp. H3. Results indicated in Figure (3) showed that peptone was the optimum nitrogen source for isoamylase production; the specific activity of the crude enzyme was $0.52 \mathrm{U} / \mathrm{mg}$. This may be because that peptone was achieved the requirements for bacterial growth and cell division. 


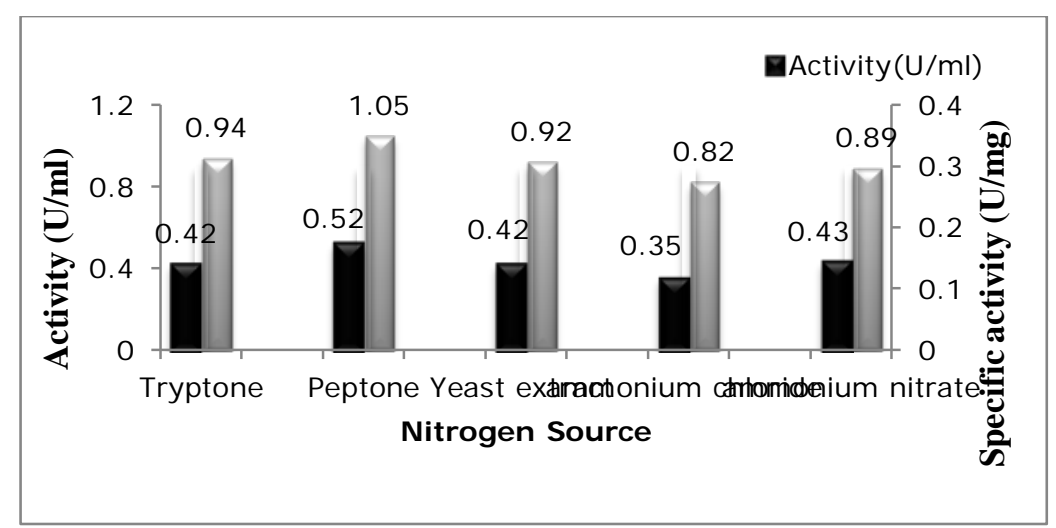

Fig (3): Effect of nitrogen source on isoamylase production by Pseudomonas sp. H3 after incubation in a shaker incubator $(150 \mathrm{rpm})$ at $28^{\circ} \mathrm{C}$ for $24 \mathrm{hr}$.

\section{Effect of nitrogen source concentration}

Five concentrations of the optimum nitrogen source (peptone) were used to determine the optimum for isoamylase production by pseudomonas $s p$. H3. Results indicated in Figure (4) showed that $0.4 \%$ of peptone was the optimum for enhance enzyme production; the specific activity of crude isoamylase in culture filtrate was $0.55 \mathrm{U} / \mathrm{mg}$. Another study found that $0.8 \%$ of peptone was the optimum for isoamylase production by Escherichia intermedia [20].

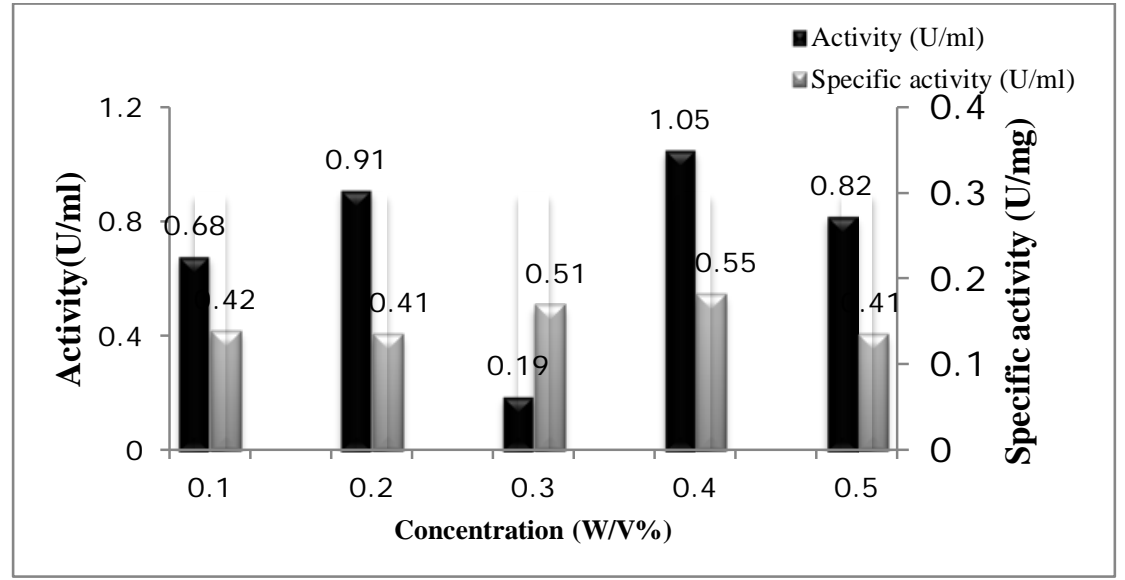

Fig (4): Effect of peptone concentration on isoamylase production by Pseudomonas sp. H3 after incubation in shaker incubator (150 rpm) at $28^{\circ}$ for $24 \mathrm{hr}$.

\section{Effect of Type of Phosphate source}

Different phosphate sources (K2HPO4, KH2PO4, Na2HPO4 and NH4H2PO4) were also used to determine the optimum for isoamylase production by Pseudomonsp sp. H3. These sources were added to the production medium at a concentration of $0.3 \%$. Results indicated in Figure (5) showed that K2HPO4 was the optimum for isoamylase production, enzyme specific activity was $0.673 \mathrm{U} / \mathrm{mg}$, this may be due to the effect of such concentration of phosphate source on buffering capacity that maintain the $\mathrm{pH}$ of the production medium which means more molecules of the buffer components present larger number of $\mathrm{H}+$ and $\mathrm{OH}^{-}$ions can be absorbed without changing the $\mathrm{pH}$ value [23]. Another study referred that $0.38 \%$ KH2PO4 was the optimum for isoamylase production by $P$. amylodermosa [24]. 


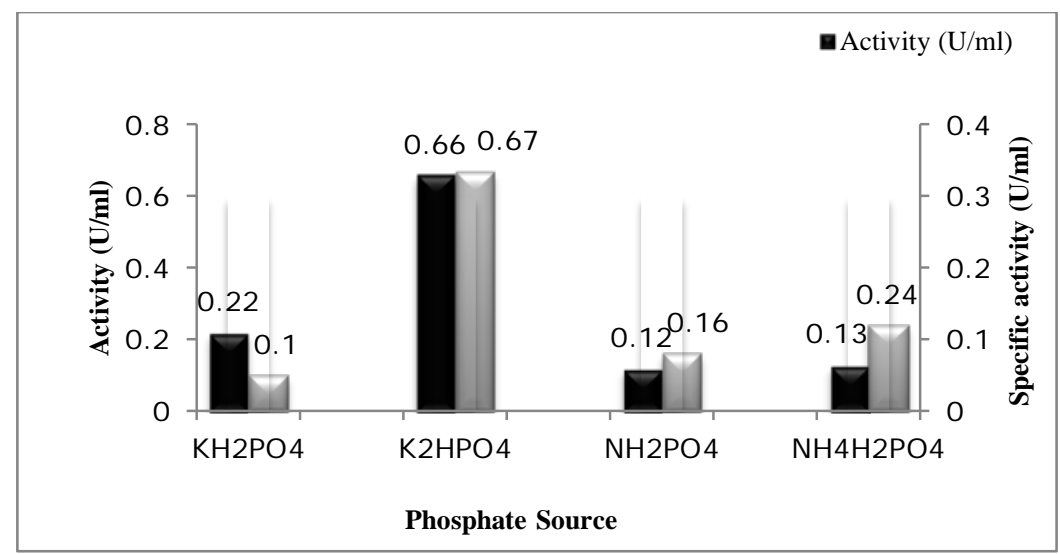

Fig (5): Effect of phosphate source on isoamylase production by Pseudomonas sp. H3 after incubation in shaker incubator $(150 \mathrm{rpm})$ at $28^{\circ} \mathrm{C}$ for $24 \mathrm{hr}$.

\section{Effect of phosphate source concentration}

Five concentrations of the optimum phosphate source (K2HPO4) were used to determine the optimum for isoamylase production by pseudomonas $s p$. H3. Results indicated in Figure (6) showed that $0.4 \%$ of K2HPO4 was the optimum for enzyme production. Specific activity of crude isoamylase in culture filtrate was $0.69 \mathrm{U} / \mathrm{mg}$. Another study showed that $0.5 \%$ of K2HPO4 was the optimum concentration for isoamylase production from A. aerugenes [25].

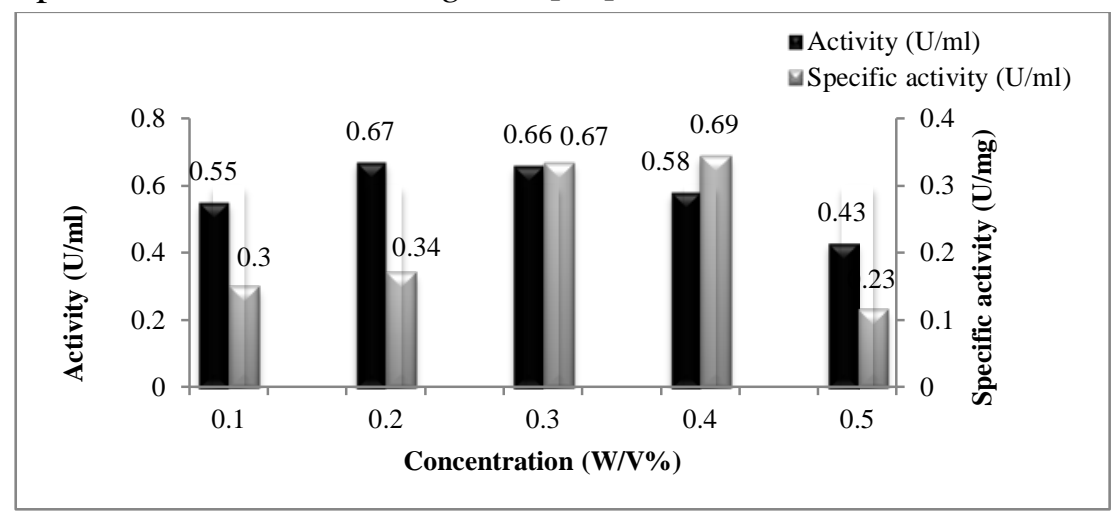

Fig (6): Effect of K2HPO4 concentration on isoamylase production by Pseudomonas sp. H3 in shaker incubator(150 rpm) after incubation at $28^{\circ} \mathrm{C}$ for $24 \mathrm{hr}$.

\section{Effect of pH}

Different $\mathrm{pH}$ values were used to determine the optimum for isoamylase production by Pseudomonas sp. H3. Results indicated in Figure(7) showed that the maximum production was obtained when the initial $\mathrm{pH}$ of the production medium was adjusted to 6.0 , enzyme specific activity in the crude filtrate was $0.843 \mathrm{U} / \mathrm{mg}$. This result was agreed with that obtained by [9], who found that the optimum $\mathrm{pH}$ value for isoamylase production by Flavobacterium odoratum was 6.0. This may be because this $\mathrm{pH}$ value may achieve the optimum conditions for the bacterial growth and enzyme production due to its effect on the properties of the culture medium including the stability of the nutrients molecules transport and ionization. $\mathrm{pH}$ value also affect the stability and catalysis of the enzyme [26]. In other study, it was found that Isoamylase purified from $P$. amyloderamosa has a $\mathrm{pH}$ optimum at $\mathrm{pH} 3.0-4.0$ [27]. 


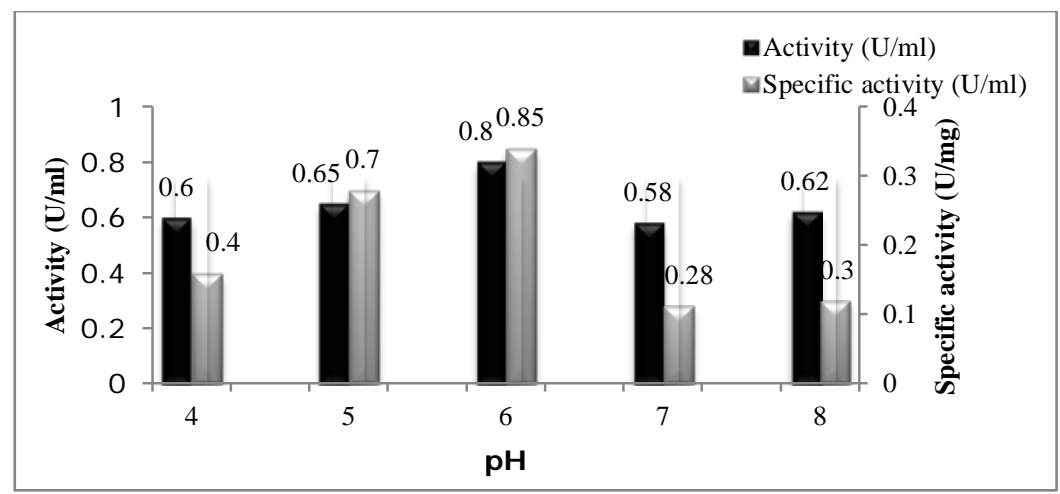

Fig (7): Effect of $\mathrm{pH}$ on isoamylase production by Pseudomonas sp. $\mathrm{H} 3$ after incubation in a shaker incubator $(50 \mathrm{rpm})$ at $28^{\circ} \mathrm{C}$ for $24 \mathrm{hr}$.

\section{Effect of temperature}

In order to determine the optimum incubation temperature for isoamylase production by Pseudomonas sp. H3. Effects of different incubation temperatures were studied to determine the optimum for this purpose. Results indicated in Figure (8) showed that the maximum production of isoamylase in culture medium was obtained at $35^{\circ} \mathrm{C}$. Specific activity of crude enzyme in culture filtrate at this temperature was 0.85 $\mathrm{U} / \mathrm{mg}$; this may be because that this temperature was the optimum for growth and propagation of the producing microorganism. [27] found that Isoamylase purified from $P$. amyloderamosa has a temperature optimum at $52^{\circ} \mathrm{C}$.

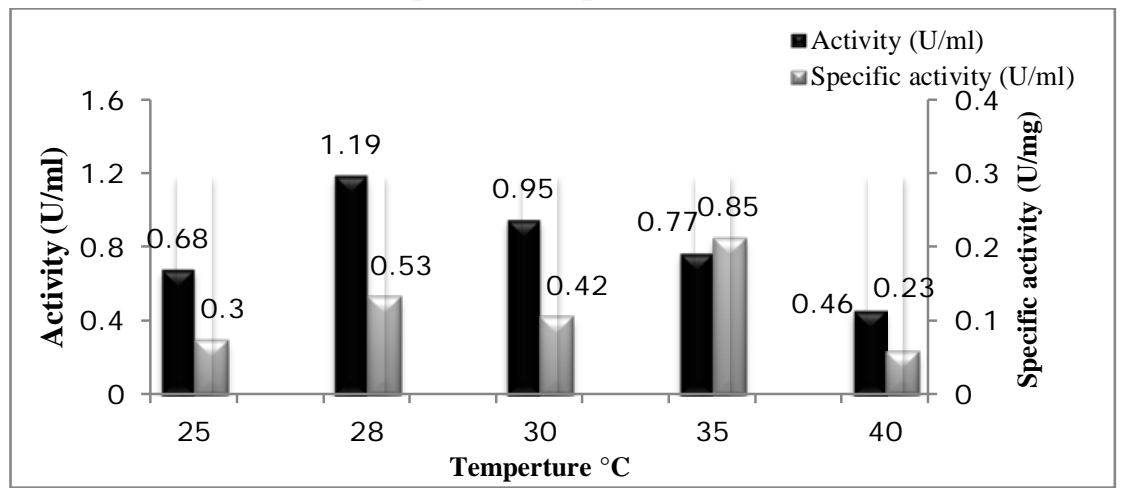

Fig (8): Effect of incubation temperature on isoamylase production by Pseudomonas $s p$. $\mathrm{H} 3$ after incubation in shaker incubator $(150 \mathrm{rpm})$ at $28^{\circ} \mathrm{C}$ for $24 \mathrm{hr}$.

\section{References}

1. Gurudeeban, S., K. Satyavani and T. Ramanthan. (2011). Production of extra cellular $\alpha$ - amylase using Bacillus megaterium isolated from white mangrove (Avicennia marina). Asian J. Biotechnol. 3: 310-316.

2. Satyanarayana, T., S.M. Noorwez, S. Kumar, J.L.U.M. Rao, M. Ezhilvannan and P. Kaur. (2004). Development of an ideal starch saccharification process using amylolytic enzymes from thermophiles. Biochem. Soc. Trans. 32: 276-278

3. Burhan, A., U. Nisa, C. Gokhan, C. Omer, A. Ashabil and G. Osman. (2003). Enzymatic properties of a novel thermostable, thermophilic, alkaline and chelator resistant amylase from an alkaliphilic Bacillus sp. Isolate ANT-6. Process Biochem. 38: 1397-1403

4. Gazi, M.R., K. Kanda, M. Yasuda and F. Kato. (2004). Optimisation of cultural conditions and some properties of radical scavenging substance from Sporobolomyces salmonicolor. Pak. J. Biol. Sci. 7: 1365-1370 
5. Regulapati, R., N.P. Malav and N.S. Gummadi. (2007). Production of Thermostable $\alpha$-amylases by solid state fermentation-A review. Am. J. Food Technol. 2: 1-11

6. Ray, R.R. (2004). $\beta$-amylases from various fungal strains. A review. Acta Microbiol. Immunol. Hung. 51: 85-95

7. Kubo, A., C. Colleoni, J.R. Dinges, Q. Lin and R.R. Lappe et al. (2010). Functions of heteromeric and homomeric isoamylase-type starch-debranching enzymes in developing maize endosperm1 (W) (OA). Plant Physiol. 153: 956-969

8. Shaptadvipa, B. and R.N. Sarma. (2009). Study on apparent amylose content in context of polymorphism information content along with indices of genetic relationship derived through SSR Markers in Birain, Bora and Chokuwa groups of traditional glutinous rice (Oryza sativa L.) of Assam. Asian J. Biochem. 4: 45-54

9. Herrero-Martinez, J.M., P.J. Schoenmakers and W.T. Kok. (2004). Determination of amylase-amylopectin ratio of starches by iodine-affinity capillary electrophoresis. J. Chromatogr. A. 1053:227-234

10. David Stevenson, G., J. Fred Eller, J. Jay-lin and E. George Inglett. (2007). Starch structures and physicochemical properties of a novel ß-glucan-enriched Oat Hydrocolloid product with and without supercritical carbon dioxide Extraction5. Am. J. Food Technol. 2: 248-256

11. Yap, P.W., A.B. Ariff, K.K. Woo and S.L. Hii. (2010). Production of cyclodextrin glycosyltransferase (CGTase) by Bacillus lehensis S8 using sago starch as carbon source. J. Biol. Sci. 10: 676-681

12. Zofia, O.B. (2007). Isoamylase from Pseudomonas amyloderamosa: Chemical and technical assessment. Ph.D. Thesis, Chicago Transit Authority.

13. Sudha, R.M., P. Chauhan, K. Dixit, S. Babu and K. Jamil. (2010). Molecular typing and probiotic attributes of a new strain of Bacillus coagulans-unique IS-2: A potential biotherapeutic agent. Genetic Eng. Biotechnol. J. 2010: 1-20.

14. Walton, S.L., K.M. Bischoff, A.R.P. van Heiningen and G.P. van Walsum. (2010). Production of lactic acid from hemicellulose extracts by Bacillus coagulans MXL-9. J. Ind. Microbiol. Biotechnol. 37: 823-830

15. Abdul-Wahab, H. S. (2008). Extraction, partial purification and Characterization of Isoamylase produced by locally isolated Psuedomonas. MSc thesis, College of Science, Al-Nahrain Univ.

16. Harada, W.; Matsuura, Y.; Kusunoki, M. and Kakudo, M. (1984). Structure and possible catalytic residues of taka- amylase. J. Biochemistry. 95:697-703

17. Kainuma, K., Kobayashi, S., and Hardest. (1978). Action of Pseudomonas isoamylase on various branched oligo-and polysaccharides. Carbohydrate Res. 61,345- 357.

18. Takahashi, K.; Abe J-I.; Kozuma T.; Yoshida M.; Nakamura N, and Hizukuris. (1996). Production and application of isoamylase from Flavobacterium odoratum. J. Enzy. And Micrbiol. Technology. 19: 456-461.

19. Bradford, M. M. (1976). A rapid and sensitive method for the quantification of microorganism quantities of protein utilizing the principle of protein- dye binding. Anal. Biochem. 72: 248-254. 
20. Bender, H. and Wallenfels K. (1961). Unter-suchungen a pullulan. Spezifischer Abbau druch ein bakterielles Enzyme. Biochem. Z. 334: 79-95.

21. Wallenfels, K.; Bender H. and Rached J.R. (1966). Pullulanase fom Aerobacter aerugenes: production in a cell- bound state. Purification and properties of the enzyme. Biochem. Biophys. Res. Commun. 22. 254-261.

22. Jer-Ying, H.; Kuo- Cheng, C. and Wen- Hwei, H. (1989). Optimization of cultivation medium composition for isoamylase production. J.Appl. Microbiol. Biotechnol.31:61-64.

23. McKee, J. R., and McKee, T. (1996). Biochemistry, an Introduction. pp. 121. USA.

24. Box, K.-C.; Chen. C. and Wen H. (1978). Optimization of cultivation composition for isoamylase production. 31: 61-64.

25. Wallenfels, K.; Bender H., and Rached J.R. (1966). Pullulanase from Aerobacter aerugenes: production in a cell- bound state. Purification and properties of the enzyme. Biochem. Biophys. Res. Commun. 22. 254-261.

26. Bull, A. T. and Bushnell, M. E. (1976). Environmental control of fungal growth. In: The filamentous fungi (eds. J. E. Smith and D. R. Berry). 2:23- 26.

27. Katsuya, Y., Mezaki, Y., Kubota, M., and Matsuura, Y. (1998). Three-dimensional structure of Pseudomonas isoamylase at 2.2 Á resolution. J. Mol. Biol. 281,885-897. 